\title{
Analysis of the Influence of Tourism Growth on Economic Growth and Human Development Index in West Java Province 2012-2018
}

\author{
Muhammad Andi Auliya Hakim ${ }^{1}$, Agustinus Suryantoro ${ }^{2}$, Mugi Rahardjo ${ }^{3}$ \\ ${ }_{1,2,3}$ Universitas Sebelas Maret, Indonesia \\ andiauliyaya@gmail.com,tinus_surya@yahoo.com,harryuns@gmail.com
}

\begin{abstract}
This study aims to determine how the influence of tourism growth as measured by the number of tourists to tourism objects, the number of tourists to accommodation, the number of hotels and accommodation, and the number of restaurants and restaurants on economic growth as measured by GRDP and Human Development Index in West Java Province. 2012-2018. The population that becomes the object of this research is the regency / city in West Java Province. The data used in this study is secondary data taken from the Central Statistics Agency (BPS) and the West Java Provincial Tourism Office. In this study using path analysis. Based on the analysis that has been carried out in this study, the results show that the variable number of tourists to accommodation and the number of restaurants and restaurants has a positive and significant effect on GRDP, while the variable number of tourists to tourism objects and the number of hotels and accommodation is not significant to the GRDP in Java Province. West. GRDP has a significant positive effect on the Human Development Index in West Java Province. The number of tourists to accommodation is the variable that has the greatest indirect effect on the Human Development Index.
\end{abstract}

\author{
Keywords \\ tourismgrowth; economic growth; \\ human development index
}

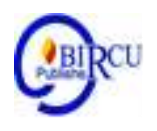

\section{Introduction}

The tourism sector has become one of the leading sectors in various countries in the world, including Indonesia as one of the prima donna for foreign exchange earners. Tourism has a significant influence on income and encourages economic growth for a country (Wu \& Zheng, 2014). Tourism is able to increase economic growth, especially economic growth in tourist areas. So it can be predicted that the tourism sector will function as a catalyst for development (agent of development) as well as accelerate the development process itself. Besides that, tourism is also able to improve the welfare of people in tourist areas. Community welfare can be seen from the increase in the Human Development Index (HDI) of an area from year to year.

The increase in the tourism sector in Indonesia can be proven by the increase in tourist arrivals to Indonesia, both domestic and foreign tourists. According to the Indonesian Central Statistics Agency, from 2015 to 2018 the contribution of the national tourism sector to GDP has increased. The contribution of the tourism sector to the National GDP in 2015 was $4.25 \%$; 2016 amounted to 4.13\%; in 2017 at 5\%; and in 2018 5.25\% (LPEM, 2018).

Tourism is all activities or tourist activities. The development of tourism has an impact on social and economic conditions for local communities through tourism activities, such as the activity of selling goods and services through hotels, restaurants, transportation services, selling handicrafts, selling tickets for tourist attractions, and so on. The development of the tourism industry in a region is very dependent on the number of tourists who come (Lie, 2004). The number of tourist visits is one form of indicator and a way to find out how much success 
in the tourism industry so that it will have a positive effect on the welfare of the community and local government in the tourist visit area. (Putra, et al., 2019).

Tourism is an industrial sector which is currently got a lot of attention from many countries in the world. The tourism sector is believed to have the ability to increase economic growth (Maciej Debski 2013). Moreover, the tourism sector is positively encouraged to be able to replace the oil and gas sector which has been the main capital in the country's foreign exchange earnings (Siswanto 2007). The advantage of the tourism sector lies in its ability to increase foreign exchange and to drive various other business sectors such as the home industry. Thus, developed countries and developing countries continue to develop and improve the quality of their country's tourism. (Amin et al, 2019)

Tourism is one of the determinants of national economic growth because it can influence the growth of other sectors in the economy (Gokovali \& Bahar, 2006) and also grows very fast during this decade (Dogru \& Bulut, 2018; Wu et al., 2000). Sustainable tourism development can be completed by creating opportunities through networking and cooperation with service providers, where stakeholder engagement, the development of locally oriented codes of conduct, and local government participation are crucial factors for sustainable tourism success (Welford \& Ytterhus in Nurlina, 2020).

West Java Province is a province located in the western part of the island of Java. West Java Province is one of the tourist destinations that has a variety of natural potentials and has a high attractiveness. The increase in the tourism sector can be proven from the number of tourist visits to tourism objects, the number of tourist visits to accommodation (lodging), the number of hotels and accommodation and the number of restaurants in West Java; which is increasing from year to year. The development of the tourism sector in West Java tends to experience an increase, although it is fluctuating. In 2008, the number of tourist visits to tourism objects in West Java was $26,230,518$ people, increasing to $45,216,254$ people in 2017 . The number of tourists to accommodation in West Java increased from $6,429,679$ people in 2008 to 18,880.(BPS, 2019).

The tourism sector is capable of being an engine of growth, by contributing to GDP growth, creating jobs, and driving foreign exchange. Likewise, economic growth also has a positive impact on tourism development (Alhowaish, 2016). The development of the tourism sector is able to increase economic growth and improve the welfare of the people of West Java. The economic growth of a region can be measured by the growth or increase in GDP each year.

Several studies on tourism development on economic growth and human development index. The development of tourism has a positive and significant impact on GDP revenue(Mudrikah, 2014). Tourism has a positive effect on economic growth and vice versa, economic growth has a positive effect on tourism. Tourism can increase foreign exchange income, create jobs, stimulate the growth of the tourism industry, so that it can trigger economic growth(Yakup, 2019).

Research conducted by (Schyff, et al., 2019) found that there was a long-term relationship between the tourism sector and economic growth and development in 1996-2016. Meanwhile, in the short term it does not show significant results or there is no relationship between tourism and economic growth. Research in India conducted by increasing the number of tourist visits and the economic growth of West Java Province can be seen in the following table: 
Table 1. Number of International and Domestic Tourists in West Java Province 2012-2016

\begin{tabular}{|c|c|c|c|c|c|}
\hline \multirow{2}{*}{ Year } & \multicolumn{2}{c|}{ Traveler } & \multirow{2}{*}{ total } & \multirow{2}{*}{ GRDP } \\
\cline { 3 - 4 } & 2012 & $1,905,378$ & $42,758,063$ & $44,663,441$ & $1,028,409,739.51$ \\
\hline 1 & 2013 & $1,794,401$ & $45,536,179$ & $47,330,580$ & $1,093,543,545.87$ \\
\hline 3 & 2014 & $1,962,639$ & $47,992,088$ & $49,954,727$ & $1,149,216,057.05$ \\
\hline 4 & 2015 & $2,027,629$ & $56,334,706$ & $58,362,335$ & $1,207,083,405.74$ \\
\hline 5 & 2016 & $4,428,094$ & $58,728,666$ & $63,156,760$ & $1,275,546,477.15$ \\
\hline
\end{tabular}

Besides being able to increase the economic growth of West Java Province as measured by an increase in GRDP, the number of tourists is also able to increase human welfare as measured by the Human Development Index (IPM) of West Java Province.

Tourism is positively related to the human development index, especially the education sector. The economic growth of ASEAN countries and the tourism sector is very important for the development of the Human Development Index. If economic growth is high and the tourism sector increases, it is expected that the Human Development Index will increase. Economic growth proxied by GDP has a positive but insignificant effect, while tourism has a significant positive effect on the human development index (Wibowo, et al., 2018).

Based on the description above, the researcher tries to find out more about the influence of tourism growth with the parameters of the number of tourists to the object, the number of tourists to accommodation, the number of hotels and accommodation and the number of restaurants in the tourism sector that have an influence on economic growth and the Human Development Index in West Java Province. The reason the researchers used West Java province was because in the last four years this province had the highest average tourist visit in Indonesia (BPS, 2019).

The purpose of this study is to find out how much influence the growth of tourism is as measured by the number of tourist visits to tourism objects, tourism growth as measured by the number of tourist visits to accommodation, tourism growth as measured by the number of hotels and accommodations and tourism growth as measured by the number of restaurants on economic growth and the Human Development Index in West Java Province in 2012-2018.

\section{Review of Literatures}

\subsection{Tourism Growth}

Tourist refers to a person. A tourist is a human being or someone who has the goal of getting out of his routine (Ene \& Baraitaru, 2010). According to the World Tourism Organization (WTO) and the International Union of Office Travel Organization (IUOTO), tourists are defined as every person who resides in a country regardless of nationality, visiting a place in the same country for a period of more than 24 hours, however not more than 6 months, the purpose of the trip can be classified as follows: (1) utilizing free time for recreation, vacation, health, education, religion and sports; (2) business, visiting family, attending meetings and conferences.

The growth of tourism in a country can be or an increase in economic tourism is shown by the number of tourists, how long they stay and the average expenditure of tourist visitors visiting tourist destinations. (Nicely \& Palakurthi, 2012). In this study, tourism growth is measured by the number of tourist visits to tourist destinations / attractions, the number of tourists to accommodation, the number of hotels and accommodations as well as the number of restaurants or restaurants in West Java Province. 


\subsection{Economic Growth}

Economic growth is generally defined as the development of activities in the economy that causes goods and services produced in society to increase and the prosperity of society increases. (Sukirno, 2015). Economic growth is a continuous process of increasing per capita output in the long run.

Economic growth can be measured by an increase in Gross Domestic Product (GDP) or Gross Regional Domestic Product (PDRB), where an increase in GDP or GRDP is considered as a measure of economic growth regardless of whether the increase is greater or less than the population growth rate or whether changes in structure economy happens or not (Suriani, et al., 2019). The GRDP used in this study is GRDP at constant prices, to determine economic growth from year to year.

\subsection{Human Development Index (HDI)}

The Human Development Index (HDI) or Human Development Index (HDI) is a composite human development index that measures the average success of a region or country in achieving several indicators ( (BPS, 2016)including: 1) Healthy life and long life (long and healthy life), as measured by life expectancy after birth. 2) Access to knowledge, which is measured by a combination of two indicators, namely the literacy rate of sedawa people and the ratio of attending education or length of schooling in primary, secondary and upper education. 3) Decent living standards as measured by GDP per capita expressed in people's purchasing power.

\subsection{Conceptual Framework and Hypotheses}

The tourism sector is considered an economic activity that has the potential to stimulate global economic growth because it is complementary to other economic activities, namely its contribution to gross domestic product (GRDP / GDP), job creation and an increase in foreign exchange. (Alhowaish, 2016). However, tourism contributes to general economic growth, but is also able to influence the economy and cultural progress of the community, increasing the welfare of the population (Cárdenas-García, et al., 2015). Population welfare or community welfare can be measured by the human development index (HDI). Therefore, tourism can affect economic growth and the human development index in an area.

\section{Research Methods}

This type of research is descriptive quantitative by testing the hypothesis that explains the causal relationship between the research variables. This study aims to examine the relationship between the variables of the number of tourist visits to tourist objects, the number of tourist visits to accommodation, the number of hotels and accommodation, the number of restaurants and restaurants; with the GRDP variable and Human Development Index (HDI). The population and sample in this study were the data recording period from 2012-2018 and all districts / cities in West Java Province totaled 24 districts / cities in West Java. This type of data is secondary data. The analysis tool used path analysis (path analysis). 


\section{Results and Discussion}

\subsection{Results}

Descriptive statistical analysis for each variable can be seen in Table 2 below:

Table 2. Descriptive Statistics

\begin{tabular}{|l|r|r|r|r|r|}
\hline & \multicolumn{1}{|c|}{$\mathrm{N}$} & \multicolumn{1}{c|}{ Minimum } & \multicolumn{1}{c|}{ Maximum } & \multicolumn{1}{c|}{ Mean } & \multicolumn{1}{c|}{ Std. Deviation } \\
\hline $\begin{array}{l}\text { Number of tourists to } \\
\text { the object }\end{array}$ & 168 & 1407.00 & 6450468.00 & 1440270.95 & 1718404.73 \\
$\begin{array}{l}\text { Number of travelers to } \\
\text { accommodation }\end{array}$ & 168 & 1102.00 & 8041208.00 & 681484.72 & 1337271.95 \\
$\begin{array}{l}\text { Number of hotels and } \\
\text { accommodation }\end{array}$ & 168 & 6.00 & 706.00 & 71.21 & 93.53 \\
$\begin{array}{l}\text { Number of restaurants \& } \\
\text { restaurants }\end{array}$ & 168 & 18.00 & 507.00 & 131.62 & 114.57 \\
GRDP & 168 & 9854633.36 & 69197858.70 & 24604547.10 & 16183811.06 \\
IPM & 168 & 60.28 & 81.06 & 68.59 & 4.61 \\
Valid N (listwise) & 168 & & & & \\
\hline
\end{tabular}

Table 2, descriptive statistics show that the standard deviation of tourism growth based on the number of tourists to tourism objects is $1,718,404.73$, greater than the average $1,440,270.95$, this means that the number of tourists to tourism objects between districts / cities in West Java has a large gap high or uneven. The largest number of tourists to tourist objects was in Bandung Regency in 2016 while the least was in Cianjur Regency in 2015.

The standard deviation of the number of tourists to accommodation is 1,337,271.95 greater than the average $681,484.72$, which means that the number of tourists to accommodation between districts / cities in West Java has a high gap. The largest number of tourists to accommodation was in Bandung City in 2018 while the lowest was in Cianjur Regency in 2015.

The standard deviation of the number of hotels and accommodation is 93.53, which is greater than the average of 71.21, which means that the number of hotels and accommodation between districts / cities in West Java has a high gap. The highest number of hotels and accommodations was in Bogor Regency in 2018, while the least number of hotels and accommodations was in Depok City in 2012.

The standard deviation of the number of restaurants and restaurants is 114.57 , lower than the average of 114.57. This means that the number of restaurants and restaurants between districts / cities in West Java is evenly distributed. The highest number of restaurants and restaurants was in Bandung Regency in 2015 while the lowest was in Tasikmalaya Regency in 2012.

The standard deviation of GRDP is $16,183,811.06$ smaller, on average 24,604,547.10 means that the GRDP between districts / cities in West Java is evenly distributed. The largest amount of GRDP in Bandung City in 2018 was 69,197,858.70, while the lowest amount of GRDP was in Cianjur district in 2012 of 9,854,633.36.

The HDI standard deviation is 4.61 , which is smaller than the average of 68.59 , which means that the HDI between districts / cities in West Java is evenly distributed. The highest HDI value was in Bandung City in 2018 amounting to 81.06 while the HDI value was the smallest in Cianjur Regency in 2012. 


\section{Hypothesis Test}

The hypotheses were analyzed using path analysis to examine the effect of each independent variable on the dependent variable. From the results of data processing with path analysis as shown in Figure 1, it can be seen that the coefficient of each variable against other variables is known as the path coefficient. In SEM analysis, the evaluation model is used in the form of squared multiple correlations for the dependent variable and the value of the Regression Weights coefficient for the independent variable which is then assessed for significance based on the $\mathrm{CR}$ value ( $\mathrm{t}$ count) for each path.

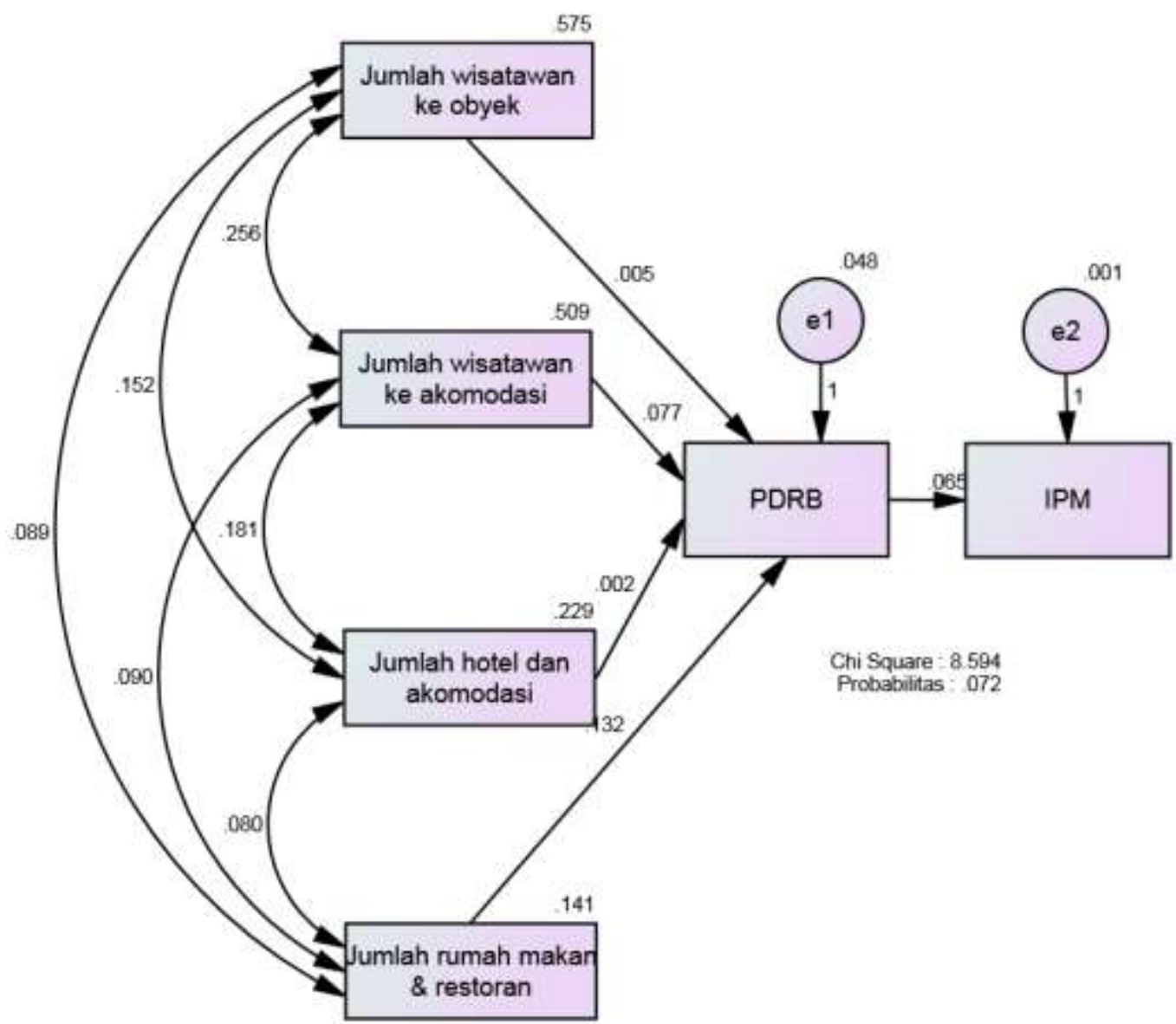

Figure 1. SEM Analysis Results Effect of Tourism Growth on Economic Growth and Human Development Index in West Java Province 2012-2018

The results of testing the proposed research hypothesis can be seen in table 3 below.

Table 3. Hypothesis Test Results

\begin{tabular}{|l|rrr|}
\hline \multicolumn{1}{|c|}{ The relationship between constructs } & Coefficient & \multicolumn{1}{c|}{ CR } & \multicolumn{1}{l|}{ P } \\
\hline Number of tourists to tourism objects $\rightarrow$ GRDP & .005 & .179 & 0.858 \\
Number of tourists to accommodation $\rightarrow$ GRDP & .077 & 2,599 & 0.009 \\
Number of hotels and accommodations $\rightarrow$ GRDP & .002 & .040 & 0.968 \\
Number of restaurants and restaurants $\rightarrow$ GRDP & .132 & 2,589 & 0.010 \\
GRDP $\rightarrow$ IPM & .065 & 8,180 & $* * *$ \\
$* * * \operatorname{sig}<0.001$
\end{tabular}


Table 3 shows that the number of tourists to accommodation, the number of restaurants and restaurants directly has a significant effect on GRDP and GRDP directly affects HDI. The results above show that the path between the number of tourists to a tourist attraction with a GRDP has a beta coefficient of 0.005 and a CR of 0.179 with a p-value $>0.05$, so statistically the variable number of tourists to a tourist attraction has no effect on GRDP (H1 is rejected). Then the path between the number of tourists to accommodation with GRDP has a beta coefficient of 0.077 and a CR of 2.599 with a p-value $<0.05$, so statistically the variable number of tourists to accommodation has an effect on GRDP (H2 is accepted). Furthermore, the path between the number of hotels and accommodation with GRDP has a beta coefficient of 0.002 and a CR of 0.040 with a p-value> 0.05 , then statistically the variable number of hotels and accommodation has no effect on GRDP (H3 is rejected). Then the path between the number of restaurants and restaurants with GRDP has a beta coefficient of 0.132 and a CR of 2.589 with a p-value $<0.05$, so statistically the variable number of restaurants and restaurants has an effect on GRDP (H4 accepted). While the GRDP variable directly affects HDI with a beta coefficient of 0.065 and $\mathrm{CR}$ of 8.180 with p-value $<0.001$ (H5 accepted).

Table 4. Indirect Effect of Tourism Growth on HDI through GRDP

\begin{tabular}{|l|c|}
\hline \multicolumn{1}{|c|}{ Indirect relationship between constructs } & Coefficient \\
\hline Number of tourists to tourism objects $\rightarrow$ GRDP $\rightarrow$ IPM & 0.008 \\
Number of tourists to accommodation $\rightarrow$ GRDP $\rightarrow$ IPM & 0.125 \\
Number of hotels and accommodations $\rightarrow$ GRDP $\rightarrow$ IPM & 0.002 \\
Number of restaurants and restaurants $\rightarrow$ GRDP $\rightarrow$ IPM & 0.113 \\
\hline
\end{tabular}

Based on table 4 of the results of the analysis of standardized indirect effects, it shows that the indirect effect of the number of tourists to tourism objects on HDI through GRDP is 0.008 or $0.8 \%$. The indirect effect of the variable number of tourists to accommodation on HDI through GRDP of 0.125 or $12.5 \%$, the indirect effect of the number of hotels and accommodation on HDI through PDRB of 0.002 or $0.2 \%$ while the indirect effect of the number of restaurants and restaurants on HDI is through GRDP of 0.113 or $11.3 \%$.

\subsection{Discussion}

These findings indicate that the number of tourists to tourism objects has no effect on GRDP. The research results are in line with (Afrizal, et al., 2019) that the number of tourists to tourism objects has no effect on GRDP. The increasing number of tourists is not followed by an increase in hotel tax revenue. The number of tourists has no effect because not all tourists who come to West Java Province stay at hotels, but some stay at their relatives' homes.

The effect of the number of tourists to accommodation on GRDP is accepted in this study. These findings indicate that the size of the GRDP in an area is influenced by the number of tourists visiting the accommodation. The longer the tourists stay in the district / city, the opportunities for tourists to spend will increase so that it will increase local revenue through revenue originating from tax object retribution, hotel tax and accommodation tax. (Suastika \& Yasa, 2017). The results of this study are in line with research conducted by(Suastika \& Yasa, 2017); (Waskito, 2013)that there is a positive and significant relationship between the variable length of stay of tourists and the variable of public welfare. The development of the tourism sector from year to year continues to increase, this means that the increase in the length of stay of tourists in tourist destination areas opens up opportunities to absorb labor which can improve the welfare of the community in the tourism sector. The increasing number of tourists to hotels and villas in tourist destinations, the more opportunities for people to improve their welfare. 
These findings indicate that the number of hotels and accommodations has no effect on GRDP. The research results are in line with(Afrizal, et al., 2019) that the number of hotels has no effect on GRDP. The increasing number of hotels if not followed by an increase in hotel tax revenue due to the occupancy rate and the average length of stay of guests who come to the hotel are very lacking.

The effect of the number of restaurants and restaurants on GRDP is accepted in this study. These findings indicate that the size of the GRDP in an area is influenced by the number of restaurants and restaurants. The results of the study are in line with that conducted by(Widayanti \& Dewanti, 2017) the number of restaurants and restaurants has a positive and significant effect on local revenue in the tourism sector. Efforts to increase local income can be carried out in various strategies, including increasing various types of taxes and levies from the business world related to tourism, such as taxes from restaurants and restaurants. The high interest of tourists who want to visit requires food and drinks as the basic needs of tourists that must be fulfilled, so that the existence of restaurants and restaurants must be provided in every tourist attraction in order to meet the needs of tourists and support PAD in the tourism sector.

The availability of restaurants and restaurants in tourist areas provides opportunities for culinary tourism entrepreneurs to introduce regional specialties. (Kurniawan, 2010) Typical food can be a potential in tourism development if it is managed and developed in an integrated, professional and orderly manner and may even be a special attraction that will attract tourists to visit which in the end also contribute positively to the foreign exchange of the tourism sector. (Widayanti \& Dewanti, 2017).

The effect of GRDP on HDI is accepted in this study. These findings indicate that the size of the HDI in an area is influenced by GRDP. The results of this study are in line with those conducted by(Muliza, et al., 2017); (Ariwuni \& Kartika, 2019) that The high GDP growth will cause consumption patterns in society to increase the level of purchasing power. The high level of purchasing power in the community will affect the increase in the human development index, because the purchasing power of the community is one of the composite indicators in the formation of HDI as seen from the income perspective. So in this case it can be concluded that the higher the economic growth will increase the human development index.

\section{Conclusion}

The results of the analysis show some quite important empirical evidence, namely that economic growth as measured by GRDP in the Regency / City of West Java Province is influenced by the number of tourists to accommodation and the number of restaurants and restaurants. However, the research results indicate that the number of tourists to tourism objects, the number of hotels and accommodations has no effect on the GRDP. GRDP has a positive influence on HDI. This means that high GRDP will increase people's purchasing power. The results of the analysis show that one of the factors indirectly influencing the HDI is the number of tourists to tourism objects, the number of tourists to the accommodation, the number of hotels and accommodation, the number of restaurants and restaurants. The biggest indirect effect is the number of tourists to the accommodation. 


\section{References}

Amin, M et al. (2019). Marketing Communication Strategy To Improve Tourism Potential. Budapest International Research and Critics Institute-Journal (BIRCI-Journal). P. 160166.

Afrizal, M., Fajar, C. \& Komalasari, Y. (2019). Dampak Jumlah Wisatawan, Jumlah Hotel, dan PDRB Terhadap Penerimaan Pajak Hotel. Jurnal Sain Manajemen, 1(1), pp. 51-63.

Alhowaish, A. K. (2016). Is tourism development a sustainable economiv growth strategy in the long run? evidence from GCC countries. Sustainability, pp. 1-10.

Ariwuni, M. \& Kartika, I. (2019). Pengaruh PDRB Dan Pengeluaran Pemerintah Terhadap IPM Dan Tingkat Kemiskinan Di Kabupaten/Kota Provinsi Bali. E-Jurnal Ekonomi Pembangunan, 8(12), pp. 2807-3114.

BPS. (2016). Indeks Pembangunan Manusia 2015. s.1.:Badan Pusat Statistik.

BPS. (2019). Indonesia Dalam Angka Tahun 2019, Jakarta: BPS.

BPS. (2019). Perkembangan Pariwisata Jawa Barat, Jawa Barat: BPS.

Cárdenas-García, P. J., Rivero, M. S. \& Fernandez, J. (2015). Does Tourism Growth Influence Economic Development?. Journal of Travel Research, 54(2), pp. 206-221.

Ene, S. G. E. \& Baraitaru, M. (2010). Sustainable Development Strategis in Domestic and International Tourism. Europen Journal of Interdisciplinary Studies, 2(2), pp. pp: 87-95.

Gilbert, D. C. (1990). Conceptual issues in the meaning of tourism. 1990, pp. pp. 4-27.

Gujarati, D. N. (2004). Basic Econometrics. Fourth Edition ed. s.l.:McGraw-Hill Companies.

Lie, L.(2004). Penggunaan Metode Regresi-Korelasi untuk Peramalan Kunjungan Wisatawan. Jurnal Ilmiah Dinamika Keariwisataan, 2(1), pp. 1-12.

LPEM. (2018). Laporan Akhir :Kajian Dampak Sektor Pariwisata Terhadap Perekonomian Indonesia. Jakarta: LPEM-FEBUI Press.

Mudrikah, A. (2014). Kontribusi sektor pariwisata terhadap GDP Indonesia tahun 2004-2009. Economic Development Analysis Journal, 3(2), pp. 362-371.

Muliza, Zulham , T. \& Seftarita, C. (2017). Analisis Pengaruh Belanja Pendidikan, Belanja Kesehatan, Tingkat Kemiskinan Dan PDRB Terhadap IPM Di Provinsi Aceh. Jurnal Perspektif Ekonomi Darussalam, 3(1), pp. 51-69.

Nicely, A. \& Palakurthi, R.(2012). Navigating through tourism options: an island perspective. International Journal of Culture, Tourism and Hospitality Research, 6(2), pp. pp: 133144.

Nurlina, (2020). Tourism Development in Langsa, Indonesia: An Overview of Tourist Attractions and Accommodation. Budapest International Research and Critics InstituteJournal (BIRCI-Journal). P.923-931

Putra, D. W. T., NoviaSanti, S., Swara, G. Y. \& Yulianti, E.(2019). Metode Topsis Dalam Sistem Pendukung Keputusan Pemilihan Objek Wisata. Jurnal Teknolf, 8(1).

Saberan, H.(2002). Produk Domestik Regional Bruto. Jakarta: Rajawali Grafindo Persada.

Schyff, T. v. d., Meyer, D. \& Ferreira, L.(2019). An analysis of impact of the tourism sector as a viable response to South Africa's growth and development challenges. Journal of International Studies, 12(1), pp. 168-183.

Suastika, I. \& Yasa, I. (2017). Pengaruh Jumlah Kunjungan Wisatawan, Lama Tinggal Wisatawan Dan Tingkat Hunian Hotel Terhadap Pendapatan Asli Daerah Dan Kesejahteraan Masyarakat Pada Kabupaten/Kota Di Provinsi Bali. e-Jurnal Ekonomi Pembangunan, 6(7), pp. 1332-1362.

Sugiyono. (2009). Metode Penelitian Kuantitatif dan Kualitatif. Bandung: CV. Alfabeta.

Sukirno. (2015). Makroekonomi Teori Pengantar Edisi Ketiga. Jakarta: Raja Grafindo Persada. 
Suriani, A., Mintarti, S. \& Musa, A. (2019). Analisis Faktor-Faktor Yang Mempengaruhi Produk Domestik Regional Bruto Dan TingkatKemiskinan Di Provinsi Kalimantan Timur. JIEM, 4(3), pp. 1-18.

Waskito, A.(2013). Dampak Investasi Asing di Sektor Pariwisata terhadap Kehidupan SosialEkonomi Masyarakat di Kepulauan Derawan. Jurnal Ilmiah Universitas Mulawarman, 1(1), pp. 1-15.

Wibowo, E., Widayat, W. \& Siswandi. (2018). Effect of Tourism GDP to Human Development: Case Study of ASEAN Countries.. Advance in Social, Education and Humanities Research, , Volume 259, pp. 107-110.

Widayanti, A. \& Dewanti, D. (2017). Analisis Pengaruh Jumlah Obyek Wisata, PDRB, Jumlah Hotel, Jumlah Restoran dan Rumah Makan, Terhadap Pendapatan Asli Daerah Sektor Pariwisata di Daerah Istimewa Yogyakarta Tahun 2010-2015. Journal of Economic Research and Social Science, 1(2).

Wu, S.-I. \& Zheng, Y. (2014). The Influence of Tourism Image and Activities Appeal on Tourist Loyalty - A Study of Tainan City in Taiwan. Journal of Management and Strategy, 5(4).

Yakup, A. (2019). Pengaruh Sektor Pariwisata terhadap Pertumbuhan Ekonomi di Indonesia. Surabaya: Unair. 